\section{Ethnographic Observations at Christ Church Burial Grounds}

\section{Julie Lierenz}

Senior, Anthropology \& Art History

Christ Church Burial Ground is a historic colonial era cemetery located in Old City Philadelphia. The cemetery is the final resting place for five signers of the Declaration of Independence, including Dr. Benjamin Rush and Benjamin Franklin. Once designated as a place of mourning, the site now functions as a tourist destination which has transformed the way the living interacts with the space. Through ethnographic observation, I wished to determine if the social rules that governed the space were different than those in other places of mourning due to the site's transition into a museum space over a place of active burial and mourning.

In the United States, burial grounds and the way in which the living interact with them have undergone many transformations. During the colonial period, the ideal resting place for the dead were small churchyard cemeteries (National Park Service, n.d.). Less ideal public burial grounds were also available during this time, and these spaces played an active role in the lives of the living and acted as public spaces for commerce, socialization and leisure well into the $19^{\text {th }}$ century (Eggner 24-26). In the late- $19^{\text {th }}$ century, cemeteries became increasingly separated from the living, fewer people visited cemeteries, and those who did[,] did so less often (Sloane 8-9). In modern America, cemeteries and the spaces of the dead are more separated from the living than ever before (Eggner 29-3; Sloane $8-17)$. In the past few decades, historians and conservationists have been pushing for the revitalization of historic cemeteries to recapture the attention and attendance of the public. These scholars argue that cemeteries preserve our history and can serve the public as outdoor museums (Miller 275, 279).

Archaeologists mainly studied cemeteries to collect information on population demographics and disease. Cemeteries also reflect the cultural and societal trends of the dead and their respective cultures. For example, headstones can serve as historic documents shedding light on lifespans, occupations, military service, and religious traditions (Bauer \& Veit 2). In cultural anthropology, British cemeteries have received recent attention by Doris Francis, Leonie Kellaher, and Georgina Neophytou. In "The Secret Garden," these scholars discuss modern mortuary practices in six London cemeteries. Through ethnographic observation and interviews, the authors attempt to answer what people do at cemeteries, and why they do them.

Morgan Meyer and Kate

Woodthorpe have also written about British cemeteries, drawing parallels between these spaces and museums. In "The Material Presence of Absence: A Dialogue Between Museums and Cemeteries," Meyer and Woodthorpe argue that both spaces are shaped by presence and absence, which in cemeteries refers to the absence of the once living and the presence of their memorials 
(1-5). Meyer and Woodthorpe also argue that cemeteries are special spaces that are governed by specific rules because they are separated and removed from everyday societies (Meyer \& Woodthorpe 1, 4).

But what are the socially implied rules that govern our behavior in a cemetery? Many of the scholars cited above point out that mourning practices and the ways in which people behave in cemeteries are culturally learned practices, but none explicitly state what these rules are (Baugher \& Veit xiiv; Meyer \& Woodthorpe 1; Francis, Kellaher \& Neophytou 26; Sloane 99). The etiquette pages of funeral home and cemetery websites, however, do outline these social rules, and generally state that visitors should follow the marked paths and remain off of the grass, and that visitors should not touch any monuments or markers that do not belong to their loved ones as it is "disrespectful" and potentially damaging to the monuments (Wilkerson Funeral home, n.d.). During the course of my observations, I hoped to determine whether visitors to Christ Church Burial Grounds followed these rules, or if they had, and how they broke them.

Despite the wealth of anthropological research of cemeteries, little has been written on how historic cemeteries factor into these analysis. Through ethnographic observation, I wished to determine if visitors to the burial grounds followed the social rules that govern actively used cemeteries, or if there were different rules for this historic cemetery. In other words, I wished to see how visitors interacted with the monuments of the space through touch or leaving mementos, and if visitors left the marked paths. I also hoped to determine what was drawing visitors into the space.

I conducted my observations on Sunday afternoons over the course of several weeks in September and October. Each session lasted roughly one and a half hours and totaled to five and a half hours of observation. I mainly conducted my observations by sitting on one of the various benches within the Burial Grounds and I did not interview any staff member or visitor.

Christ Church was established in Philadelphia in 1695. During the early years of the church, members of the congregation were buried in the small church yard next to the original building (Christ Church, n.d.). In 1719, the church purchased a two acer plot of land on $5^{\text {th }}$ and Arch Streets, which at the time was located in the suburbs of the city, to act as the new cemetery for the congregation (Dorr 48; Christ Church 62-63). The cemetery was actively used for the next 150 years, but eventually fell out of use and into disrepair until it was finally closed to the public in 1977. During this period, the vast majority of the 6,500 original grave markers were damaged and lost with only 1,200 surviving today (Cultural Landscape Foundation, n.d.). In 2003, the Christ Church Preservation Trust began a project to repair 150 of the remaining monuments and tend the overgrown grounds of the site (Christ Church, n.d.). The Burial Grounds reopened to the public in 2003, and is now open to visitors seven days a week, weather permitting, and offers daily guided tours of 
the cemetery and special events like "death tours" in the fall.

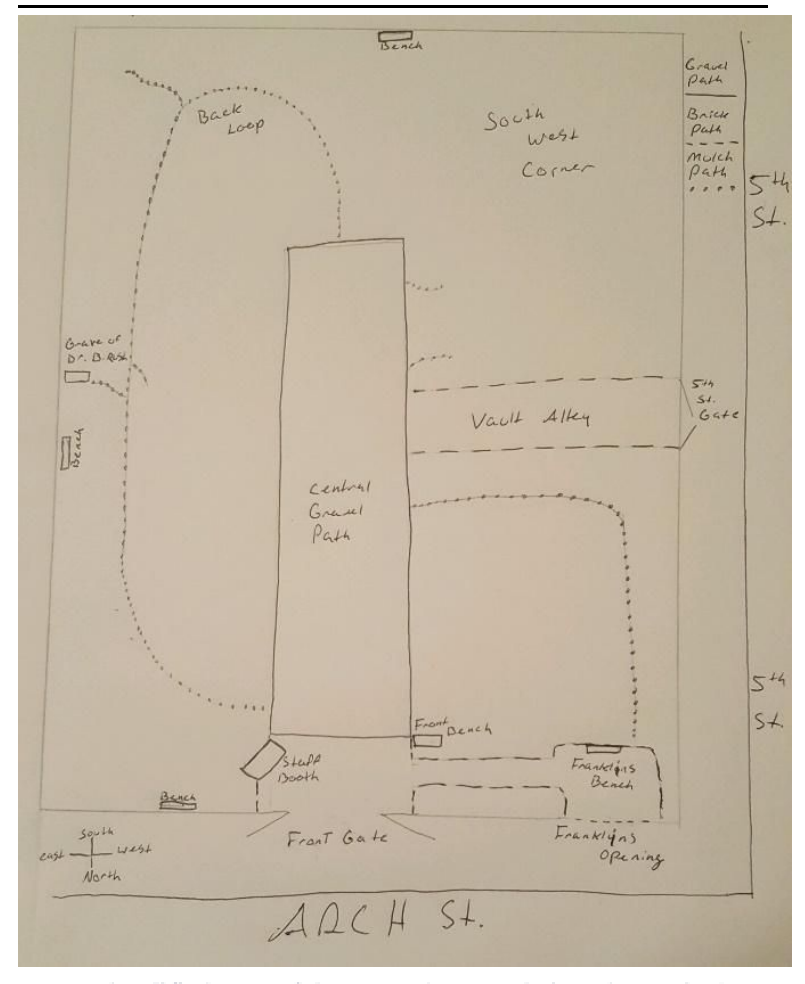

Simplificd Map of the Space (Map and photo by Author)

The open air cemetery is enclosed by a tall brick walls on all sides. In 1858, a section of the wall directly next to the crypt of Franklin was replaced with metal bars by John Rice, John Skirving, and the Wood \& Perot Manufacturing Company to allow people on the street to interact with the grave (Dixon 2017). Because of the architecture of the fence, the only view into the space from the outside are the entrance and Franklin's opening. The landscape of the site is dotted with burial monuments, benches, and several mature trees that provide sporadic shade throughout the cemetery. Within the walls of the cemetery the views of the city are hidden, but the sounds of traffic and construction dominate the area. The site is also segmented by a series of pathways: the main walkway of the space is a wide gravel path that runs down the center of the space to which all other paths connect. There are also two brick paths within the space: one leading to the crypt of Franklin, and the other leading to an unused gate on $5^{\text {th }}$ Street. Mulch paths run through various points of the site, creating pathways to important monuments, benches, and other larger paths.

The grave markers of the cemetery are mainly thin, oblong stele, or low-rising, vault-style crypts. There are also numerous tabletop-style graves, and several pyramidal or obelisk-like monuments. The vast majority of the monuments were constructed out of marble, and prolonged exposure to the elements and acidic rain of the city has left many inscriptions unreadable. Additionally, the thin nature of the oblong headstones has caused them to break apart with time: many of these monuments have been reduced to small stone fragments with no readable inscriptions.

As Baugher and Veit point out in "The Archaeology of American Cemeteries and Gravemarkers," cemeteries preserve important social and cultural practices of the individuals interred. For example, the vault tombs can shed light on the structuring and importance of family relationships. The top of the marble slabs generally list one male as the head of the household, and the following interred individuals are named in relationship to that man. This trend can also be seen on other monuments where women are listed as the wife of someone, even if they are buried alone. These monuments show the importance of family connections; this importance can also be seen in the grave 
marker for an infant that as the marker states, only lived for three hours. Even though this infant did not fulfill a life with their family, the kinship connection that the parents shared with the infant was still important enough to dedicate a monument to. The staff has also highlighted important societal markers through the inclusion of plaques for select graves. These plaques are generally given to men with some type of military association, and their distinction within the modern context of the graveyard shows that their military status is an important aspect of how they are currently viewed by visitors.

In "Cemeteries," Keith Eggner states that "cemeteries keep the dead alive" (13-12). Through visiting Christ Church Burial Grounds, visitors are able to interact with historical figures in a uniquely personal way. Visitors are invited to directly interact with Benjamin Franklin's grave through the tradition of leaving a penny on his marble crypt during a visit or in passing on the street. ${ }^{1}$ The penny tradition stems from one of Franklin's famous aphorisms: " A penny saved is a penny earned." This practice is explained in both the official Christ Church Burial Ground website and tourist websites like Visit Philadelphia. Some visitors have extended this tradition, leaving pennies on the vaults and headstones of other declaration signers. To some visitors, the

\footnotetext{
${ }^{1}$ Not all visitors were comfortable directly interacting with Franklin's crypt. One woman who wanted to get a better look at the inscription on Franklin's grave, but refused to directly touch it, grabbed the bars in the fence and leaned her body over the crypt, successfully avoiding contact.
}

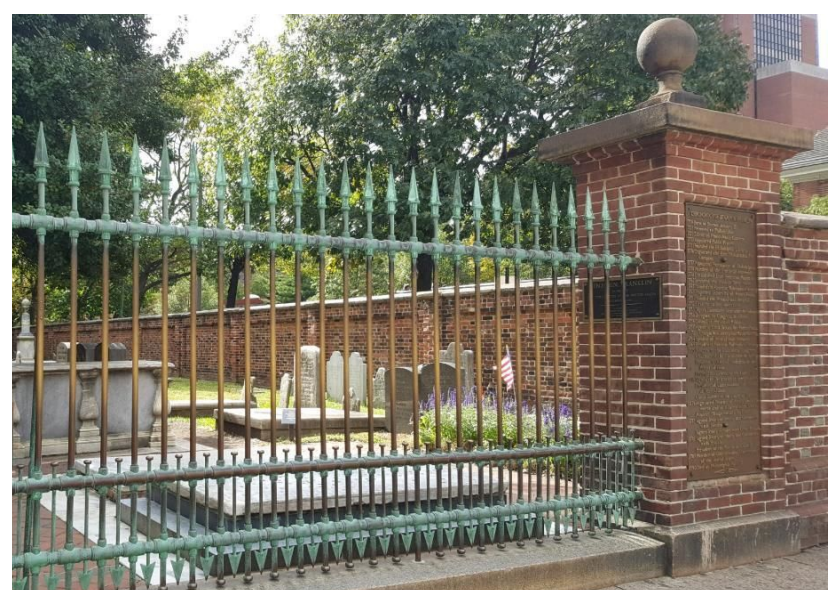

Franklins Opening in the Fence (Photo by Author) specifics of the anecdote is not as important as is the physical act of leaving coins. During my observations I witnessed one man walking on the street outside of the cemetery pause at Franklin's opening in the fence, rummage through his pockets and then dump a handful of change onto the crypt before continuing on his walk. Leaving mementos on graves is a common practice that can also be found in modern cemeteries, and also allows visitors and mourners to directly interact with the dead in a personal and unique way (Meyer \& Woodthorpe 1-3).

One focus of my observations was how people on the street interacted with the interior through Franklin's Opening. These observations lead me to the conclusion that many discover the space and enter by chance, and that Franklin's opening was one of the major aspects that drew people into the space. For example, I observed one group walking down the $5^{\text {th }}$ St. sidewalk carrying Marshals' shopping bags as they approached the Arch St. intersection. While they waited to cross the street, one member of the group spotted the opening in the fence 
and beckoned for his companions to see what the small crowd was gathered around. They stopped at the opening for a moment before the man asked his companions if they wanted to go in. They debated momentarily, almost apathetically, before deciding to enter the space. After walking through the site, the group left in a different direction than their original path. This group bears several markers of chance visitors: the shopping bags show that they had a prior engagement in the area; the question of whether they should enter shows that they had no prior plans to enter the space; and their change of direction upon leaving could indicate that they have no set destination and are merely exploring the neighborhood.

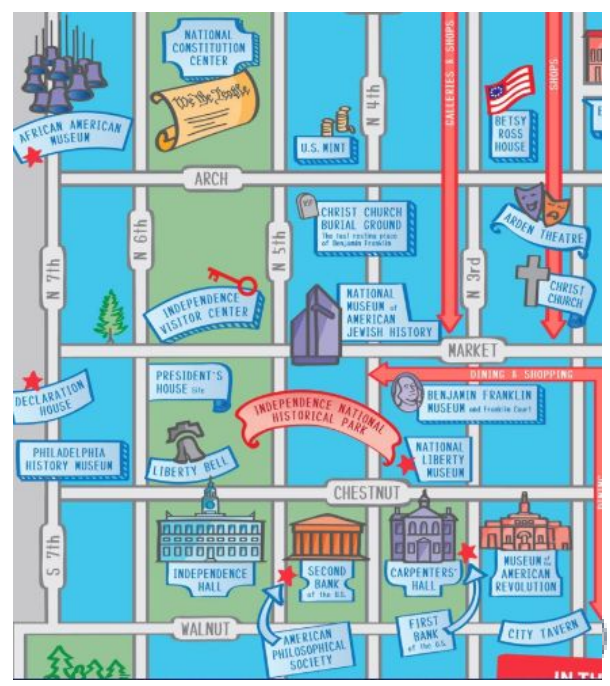

Section from a Tourist Map of Philadelphia

Franklin's opening is also a large draw for tour groups. Old City plays host to a wide variety of tour services ranging from open-air bus tours and walking tours, to Segway tours, and many of these tours mention or stop at the burial grounds. Some tours are led by guides in Revolutionary-Era costumes while others cater to non-English speaking visitors. I observed one guide lead a large group up to Franklin's opening and describe the site briefly in German before holding up a penny prominently for all to see. In a slightly exaggerated motion, she reached through the fence and dropped the penny on Franklin's crypt before stepping aside to allow her group to do the same. These groups do not stay at the fence for long - the German tour group, for example, only stayed for roughly 3 minutes.

For my observations, I also focused on how people entered the space through the main gate; these observations strengthened my conclusion that many visitors simply happen upon the space. Most people that I observed entering through the main gate paused at the entrance for several moments before either moving on or continuing inside.

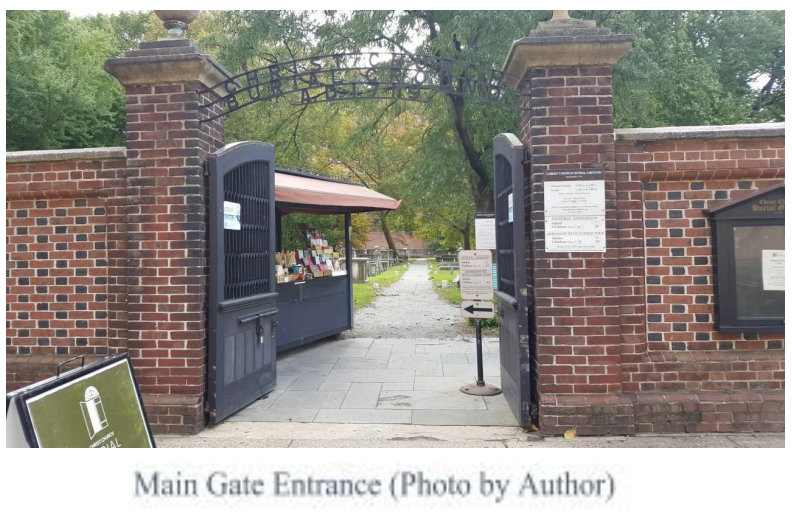

Passersbys stopped to inspect the area of the grounds visible through the fence, or to look at the admissions information posted outside, sometimes conferring with their companions briefly before entering or departing. Very few people that I observed entered the space quickly, and because the people I observed paused for such a relatively long time in the entrance, it is 
likely that those who did enter decided to do so in the gateway rather than by some predetermined plan. Furthermore, not everyone that entered into the space did so to explore the graveyard. During my observations I witnessed several individuals and groups entering the space to purchase water or to ask for directions to the nearest parking lot, public restroom, or tourist sites before moving on.

Upon entering through the gate, visitors are immediately confronted by a small open-air booth run by the grounds staff. During my observations the grounds staff mainly remained in this booth, only leaving to lead tours or perform simple maintenance for the site. Visitors are required to purchase admittance to the site here before they can proceed into the rest of the space. Visitors can also purchase a map of the site, revolutionary era books, magnets and cards with Franklin's image and other colonial-themed trinkets. After purchasing admission, the staff almost always directs visitors to the grave of Franklin. The recommendation to visit Franklin is the only direction that the staff provide to visitors without further questions being asked; there is no orientation to the space or guidelines for behavior provided upon entering.

There is one sign in the site that does explicitly state a rule for the space. This sign is located next to the brick path leading to the closed $5^{\text {th }}$ St. gate, and it instructs visitors not to step or walk on the grave markers. This sign is quite small, and the majority of visitors did not enter or spend much time in the area where it is visible.
The only other sign within the site that states a rule of the space is a small sign at the end of the central path requesting no strollers beyond that point. Because these signs are obscured in the site, and because the staff does not patrol the grounds like security guards or docents, there is no enforcement of these rules. Visitors can ignore and break these rules with no repercussions.

After passing through the gates and purchasing a ticket, the vast majority of visitors headed directly for Franklin's grave with only two visitors not visiting Franklin at all during my observations. After visiting Franklin's grave, some visitors backtrack up the paved path and then to the central gravel path, but most visitors continue onto the western mulch path. This path then connects with the central path and many visitors leave after completing this loop having spent anywhere between 10 and 25 minutes in the site. Slightly less than half of the visitors that I observed explored the eastern mulch path, and none of the visitors entered into the south west corner of the graveyard.

Before I began my observations, I assumed that the majority of visitors would not wander from the marked paths. Overall, most of the visitors that I observed did not stray from the paths, but there were several visitors that did. Visitors who carried maps of the site were more likely to leave the paths to approach monuments listed on the map, or out of inattention to the path itself while reading and walking. I also observed numerous visitors without maps straying from the paths and following in the footsteps of those with maps ahead of them. Other 
visitors cut through the grass near the corners of a path to save a few steps, or to approach a far-away monument of interest. I also assumed that most visitors would not touch the monuments of the site before I conducted my observations. With the exception of leaving change on Franklin's grave, most visitors did not directly interact with the graves within the space. I did, however, witness several visitors leaning on the crypt vault behind Franklin's bench and one other vault grave on in the northwestern portion of the cemetery.

In contrast to the visitors, the staff was not bound by these supposed restrictions within the space. Because the staff is responsible for the maintenance of the space, they are authorized to move freely through the headstones and touch the monuments in order to perform their jobs. The staff's specialized knowledge of the burial grounds and the surrounding area also differentiates them from visitors. Most visitors to the site are tourists, and are therefore unfamiliar with the history of the burial grounds or the layout of the surrounding area; there is an unequal balance of knowledge, and by extension power, between staff and visitors. However, this unequal balance of power is never acted upon as the staff does not patrol the grounds or reprimand visitors for breaking the implied or stated rules of the space.

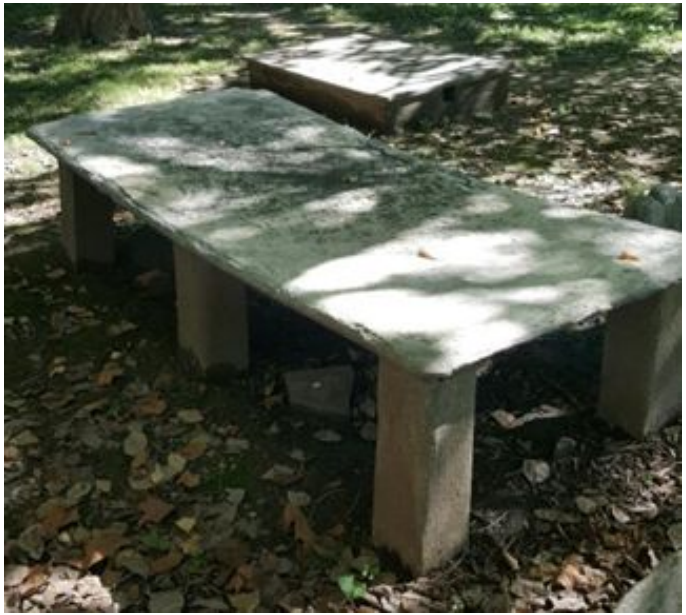

Example of a Tabletop Grave (Photo by Author)

Because visitors to Christ Church Burial Grounds did not follow the social rules of remaining on paths and not touching monuments, it can be said that the visitors are only governed by the rules that they create for themselves within the space. One visitor perfectly exemplifies this. On the third day of my observations, I witnessed a young man stride into the cemetery with confidence and purpose. He was dressed in a casual manner, wearing jeans and a tee-shirt featuring a zombified Mona Lisa. He nearly blew past the staff booth without paying admission before a staff member politely stopped him. After pausing briefly to pay the toll, he continued into the space at an accelerated pace until suddenly he dropped to his knees to take a photograph. He sprang back up almost as quickly as he had dropped and continued along the path. He continued speeding through the site taking pictures with his gaze high, indicating that he was surveying the area instead of looking at specific monuments. Eventually he left the marked paths and began to wander through the monuments before taking a seat on a 
table top grave, most likely mistaking the monument for a bench. He remained seated on top of the grave for roughly 4 minutes checking his phone. In that time no one approached him about being off of the path or for sitting on a grave, illustrating that the only governance of the site is made by the visitors themselves.

Throughout my observations I was made aware of how my presence affected the space and the actions of those around me. For example, while I was making observations from the front bench, I could see that groups visiting Franklin's grave often sat on the bench and talked for an extended period of time. However when I moved to that bench to observe the area, only one other visitor utilized the bench and groups did not stay in the area for as long. Similarly, while I was making observations in that area I saw several visitors through the fence watching me in a somewhat confused manner, perhaps wondering what I was writing about. Moreover, on my last day of observation I attempted to trail a group of visitors in order to track their entire visit within the expansive space. I followed them at a distance on the paths, and stopped in front of plaques to make it seem as if I was recording the inscriptions and not the movements of the group. My movements were noticed by the group near the end of their visit, and one member even approached me to ask if I was a member of the staff. She then approached a staff member with a question which leads me to believe that she would have asked me the same thing if I had said yes.
Christ Church Burial Grounds is a place that might not have any universal rules, but it is a place of many dualities. The focus of the site is death yet, it is maintained for the living who still visit hundreds of years after most burials were sealed. The site is home to one of the most famous men of the revolution and American history, yet the exact locations and identities of thousands of burials have been lost to time. After the completion of my observations I am left with three main conclusions about the space: first, Ben Franklin is the main attraction and focus of the site; second, most visitors end up at the site by chance rather than by planning; and finally, the rules of the space are not explicitly stated or enforced which means that visitors are solely governed by what they interpret the rules to be.

Christ Church Burial Grounds exists in a loosely-defined category between museum space and a place of mourning. The burials of the space have sacralized the grounds, (Eggner 23) but the passage of time has lessened the effects and rules of mourning and the spaces of the dead. The conclusions of this study shows that historic cemeteries like Chris Church Burial

Grounds are not governed by the same rules as actively used cemeteries which means that there is no universal way to analyze how the living interact with the dead and how cemeteries function in the modern world. 


\section{REFERENCES}

Baugher, Sherene and Richard Veit. 2014. The Archaeology of American Cemeteries and Gravemarkers. Gainesville: University Press of Florida.

Christ Church. n.d. "About the Burial Grounds." Accessed November 15, 2018 at https://www.christchurchphila.org/about-the-burial-grounds/

Christ Church (Philadelphia, Pa). 1953. The Story of Christ Church in Philadelphia. Philadelphia.

The Cultural Landscape Foundation. n.d. "Christ Church Burial Ground." Accessed November 15, 2018 at https://tclf.org/landscapes/christ-church-burial-ground

Dixon, Mark. 2017. "How Franklins' Grave Became a Monument and Philadelphians Were Persuaded to Like it." Hidden City Philadelphia. Accessed November 15, 2018 at https://hiddencityphila.org/2017/04/behind-the-publicity-stunt-at-benjamin-franklins-grav e/

Dorr, Benjamin. 1841. A Historical Account of Christ Church, Philadelphia: From its Foundation, A.D. 1695 to A.D. 1841: And St. Peters and St. James's, Until the Separation of the Churches. New York: Swords, Stanford and Co..

Eggner, Keith. 2010. Cemeteries. New York: W. W. Norton and Company Inc..

Francis, Doris, Leonie Kellaher and Georgina Neophytou. 2005. The Secret Cemetery. New York: Berg.

Meyer, Morgan, Kate Woodthorpe. 2008. "The Material Presence of Absence: A Dialogue Between Museums and Cemeteries." Sociological Research Online. http://www.socresonline.org.uk/13/5/1.html>

Miller, Sarah E. 2015. "Cemeteries as Participatory Museums." Advances in Archaeological Practice 3(3): 275-290. DOI: 10.7183/2326-3768.3.3.275

Sloane, David Charles. 2018. Is the Cemetery Dead?. Chicago: The University of Chicago Press.

U.S. Department of the Interior, National Park Service. n.d. "Burial Customs and Cemeteries in American History." Accessed November 15, 2018. https://www.nps.gov/nr/publications/bulletins/nrb41/nrb41_5.htm

Visit Philadelphia. n.d. "Christ Church Burial Grounds." Accessed November 15, 2018 at https://www.visitphilly.com/things-to-do/attractions/christ-church-burial-ground/

Wilkerson Funeral Home \& Crematory. n.d. "Etiquette: Understanding Appropriate Funeral Conduct." Accessed November 12, 2018. http://m.wilkersonfuneralhome.com/resources/funeral-etiquette 